ACTA CHEMICA BCANDINA VICA (1964) $266-279$

\title{
The Complex Formation between Iron (III) Ion and Sulfosalicylic Acid
}

\author{
ALLAN A GREN \\ Department of Chemistry, Royal Pharmaceutical Institute, Stockholm; Department of Inorganic \\ Chemistry, Royal Institute of Technology, Stockholm, Sweden
}

\begin{abstract}
Dhenols are characterized by, amongst other reactions, the colour which is formed with a solution of iron (III) chloride. The coloured substance formed is a complex built up by iron (III) ion and one or more phenol molecules.

Sulfosalicylic acid and iron (III) give a violet colour in a rather strongly acidic solution. When the $\mathrm{pH}$ is increased the colour shifts over orange to yellow.
\end{abstract}

Previous work. Wesp and Brode ${ }^{1}$ made a review, the composition and colour of the complexes formed from 44 phenols and iron (III). Schwarzenbach and coworkers have written several papers concerning the stability of such complexes, most of them being cited in ?. Foley and Anderson investigated the system iron (III) + sulfosalicylic acid spectrophotometrically. They concluded that the colour change might depend upon a dissociation of the complex. In several buffer systems, having $\mathrm{pH}$ values up to 7.75 , they found that the complex was built up from 1 molecule sulfosalicylic acid and 1 atom of iron (III). The apparent equilibrium constant $K=\frac{[\mathrm{Fe}] \cdot[\mathrm{R}]}{[\mathrm{Fe}]}$ was found to be $1.3 \cdot 10^{-5}$ at $\mathrm{pH} 2.38$ and $2.2 \cdot 10^{-5}$ at $\mathrm{pH}$ 5.3. [R] is here the total content of sulfoselicylic acid "without correction for ionization".

Banks and Patterson " in a polarographic investigation of the same complexes showed that the yellow colour obtained in neutral or alkaline solution is due to a complex built up from 1 atom iron and 3 molecules of sulfosalicylic acid. They estimated the equilibrium constant for the reaction

$$
\mathrm{FeR} \mathrm{R}^{-3}+3 \mathrm{H}_{2} \mathrm{O}=\mathrm{Fe}^{+3}+3 \mathrm{RH}^{-2}+3 \mathrm{OH}^{-}
$$

$\begin{array}{ll}\text { to be } 10^{-4} \mathrm{C}^{3}(\mathrm{C}=\text { moles/litre }) . & \mathrm{R} \text { is } \\ \text { the temperature } 25^{\circ} \mathrm{C} \text {. } & -\mathrm{SO}_{3}\end{array}$

Kennard and Johnson s used the complex formation between iron (III) and sulfosslicylic acid in a photometric determination of iron. They showed that the three complexes have extinction maxima at 500, 460 and $420 \mathrm{~m} \mu$ resp. and that the complexes are stable around $\mathrm{pH} 1.5,5.0$ and 8.2 resp. 


\section{THEORY}

Sulfosalicylic acid is a tribasic acid. In water the sulfonic group is completely ionized. Thus the ions $\mathrm{RH}_{2}^{-}$and $\mathrm{RH}^{-2}$ are present but hardly any ions, $\mathbf{R}^{-3}$, since phenols are very weak acids. When 1 molecule $R$ is bound to $F e$ (III), a chelate compound is formed:

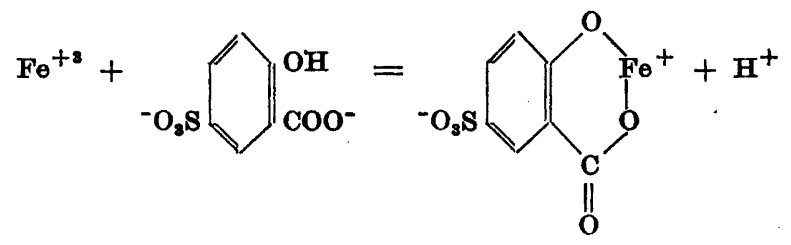

This compound is a sulfonic acid which is assumed to be completely ionized.

There is a possibility that the complex $\mathrm{FeRH}^{+}$is formed. The experimental results may however be explained without including this possibility in the theory.

The higher complexes are formed in an analogous manner.

This investigation was made to estimate the numerical values of the complexity constants, defined as follows:

$$
\begin{array}{ll}
\mathrm{Fe}^{+3}+\mathrm{RH}^{-2}=\mathrm{H}^{+}+\mathrm{FeR} & x_{1}=\frac{\mathrm{h} \cdot[\mathrm{FeR}]}{[\mathrm{RH}] \cdot[\mathrm{Fe}]} \\
\mathrm{Fe}^{+3}+2 \mathrm{RH}^{-2}=2 \mathrm{H}^{+}+\mathrm{FeR}_{2}^{-3} & x_{2}=\frac{h^{2} \cdot[\mathrm{FeR}]}{[\mathrm{RH}]^{2} \cdot[\mathrm{Fe}]}
\end{array}
$$

and so on. Or generally written:

$$
\begin{aligned}
\mathrm{Fe}^{+3}+\mathrm{n} \mathrm{RH}^{-2}=\mathrm{n} \mathrm{H}^{+}+\mathrm{FeR}_{\mathrm{n}}^{3-3 \mathrm{n}} \\
x_{\mathrm{n}}=\frac{\mathrm{h}^{\mathrm{n}} \cdot\left[\mathrm{FeR}_{\mathrm{n}}\right]}{[\mathrm{RH}]^{\mathrm{n}} \cdot[\mathrm{Fe}]}
\end{aligned}
$$

where $\mathrm{h}$ is the hydrogen ion concentration (in $\mathrm{mC}=$ millimoles/litre) and [ ] the concentration of the substance indicated. The signs for the electrical charges are omitted.

To estimate these complexity constants, $h$ and $[\mathrm{Fe}]$ can be measured potentiometrically. $\left[\mathrm{FeR}_{\mathrm{n}}\right]$ can be determined photometrically. Both these methods have been used here. The measurements were made at $25.0^{\circ} \mathrm{C}$ and, to all solutions, $\mathrm{NaClO}_{4}$ was added up to a total concentration of $3000 \mathrm{mC} \mathrm{ClO}_{4}^{-}$. This ion strength was chosen because Hedström's ${ }^{6}$ investigations on the hydrolysis of iron (III) and iron (II) are made at this ionic strength and thus his results could be used.

As shown by Sutton ${ }^{7}, \mathrm{ClO}_{4}^{-}$has a weak complex forming tendency but this tendency does not influence the results when the concentration of this ion is great and constant. It is assumed that the activity factors are constant and hence the concentrations may be used instead of activities in the equilibria. 
Potentiometric determinations

The con centration of free iron (III) ion was measured in the presence of $a$ constant amount of iron (II) with a platinum electrode. The hydrogen ion concentration was measured with a glass electrode. As a reference electrode, a silver-silver chloride electrode in $100 \mathrm{mC} \mathrm{NaCl}$ and $3000 \mathrm{mC} \mathrm{NaClO}$ was used. Thus the electromotive force (emf) of the following cells were measured:

+ Glass electrode $\left|\mathbf{H}^{+}\right|$Reference electrode -

$+\mathrm{Pt}\left|\mathrm{Fe}^{+3}, \mathrm{Fe}^{+2}\right|$ Reference electrode -

The emf of the first cell is given by the equation

$E_{\mathrm{Gl}}=E_{0, \mathrm{G} 1}+59.16 \log \mathrm{h}+E_{\mathrm{j}}$

where $E_{0, \mathrm{G} 1}$ is a constant (in $\mathrm{mV}$ ) and $E_{\mathrm{j}}$ the liquid junction potential. The glass electrode used changed its potential in the theoretically expected manner, as shown by a separate titration. $E_{\mathrm{j}}$ is approximately $=-0.018 \mathrm{~h}$ under conditions used in this investigation, as shown by Biedermann and Sillén ${ }^{8}$.

The emf of the second cell is given by the equation

$$
E_{\mathrm{Pt}}=E_{0, \mathrm{Pt}}+59.16 \log \frac{\left[\mathrm{Fe}^{+3}\right]}{\left[\mathrm{Fe}^{+2}\right]}+E_{\mathrm{j}}
$$

where $E_{0, \mathrm{Pt}}$ is a constant. This equation can be transformed

$$
E=E_{\mathrm{Pt}}-E_{\mathrm{j}}=E_{0, \mathrm{Pt}}+59.16 \log \frac{[\mathrm{Fe}]_{\mathrm{t}}}{\left[\mathrm{Fe}^{+2}\right]}-59.16 \log (\mathrm{b}+1)
$$

where $b=\frac{[\mathrm{Fe}]_{t}-\left[\mathrm{Fe}^{+3}\right]}{\left[\mathrm{Fe}^{+3}\right]}$ and $[\mathrm{Fe}]_{t}$ is the total concentration of iron (III). If the total concentration of iron (III) and of iron (II) are each constant during an experiment, this equation can be written

$E=E_{0}-59.16 \log (\mathrm{b}+1)$

where $E_{0}=E_{0, \mathrm{Pt}}+59.16 \log \frac{[\mathrm{Fe}]_{\mathrm{t}}}{\left[\mathrm{Fe}^{+2}\right]}$

In order to calculate the complexity constants the following equation was used:

$$
\begin{gathered}
{[\mathrm{Fe}]_{\mathrm{t}}=[\mathrm{Fe}]+[\mathrm{FeOH}]+\left[\mathrm{Fe}(\mathrm{OH})_{2}\right]+2\left[\mathrm{Fe}_{2}(\mathrm{OH})_{2}\right]+[\mathrm{FeR}]+\left[\mathrm{FeR}_{2}\right]+} \\
+\left[\mathrm{FeR}_{3}\right]
\end{gathered}
$$

The hydroxyl complexes were found by Hedström ${ }^{6}$ and the equilibrium constants are defined by

$$
x_{\mathrm{nm}}=\frac{\mathrm{h}^{\mathrm{n}} \cdot\left[\mathrm{Fe}_{\mathrm{n}}(\mathrm{OH})_{\mathrm{m}}\right]}{[\mathrm{Fe}]^{\mathrm{n}}}
$$

By combining equations (1) and (2):

$$
\begin{gathered}
{[\mathrm{Fe}]_{\mathrm{t}}=[\mathrm{Fe}]+\frac{\varkappa_{11}[\mathrm{Fe}]}{\mathrm{h}}+\frac{\varkappa_{12}[\mathrm{Fe}]}{\mathrm{h}^{2}}+2 \frac{\varkappa_{22}[\mathrm{Fe}]^{2}}{\mathrm{~h}^{2}}+x_{1} \frac{[\mathrm{RH}]}{\mathrm{h}}+} \\
+\varkappa_{2} \frac{[\mathrm{RH}]^{2}}{\mathrm{~h}^{2}}+\varkappa_{3} \frac{[\mathrm{RH}]^{3}}{\mathrm{~h}^{3}}
\end{gathered}
$$


or by transforming

$$
\frac{[\mathrm{Fe}]_{\mathrm{t}}-[\mathrm{Fe}]}{[\mathrm{Fe}]}=\mathrm{b}=x^{\prime}+x_{1} \frac{[\mathrm{RH}]}{\mathrm{h}}+x_{2} \frac{[\mathrm{RH}]^{2}}{\mathrm{~h}^{2}}+x_{3} \frac{[\mathrm{RH}]^{3}}{\mathrm{~h}^{3}}
$$

where the small correction term $x^{\prime}$ is defined by

$$
x^{\prime}=\frac{x_{11}}{\mathrm{~h}}+\frac{x_{12}}{\mathrm{~h}^{2}}+2 \frac{x_{22}[\mathrm{Fe}]}{\mathrm{h}^{2}}
$$

The numerical values of the equilibrium constants of the hydroxyl complexes are, according to Hedström, $x_{11}=0.90, x_{12}=0.49$ and $x_{22}=1.22$.

If the last term of equation (3) is assumed to be very small compared with the other terms, the following equation is obtained:

$$
\left(\mathrm{b}-x^{\prime}\right) \frac{\mathrm{h}}{[\mathrm{RH}]}=x_{1}+x_{2} \cdot \frac{[\mathrm{RH}]}{\mathrm{h}}
$$

The value of the left member can be calculated from experimental data. If this member is plotted against the function $[\mathrm{RH}] / \mathrm{h}$ a straight line should be obtained, the intercept being $\varkappa_{1}$ and the slope $\varkappa_{2}$.

In order to calculate $[\mathrm{RH}]$ the dissociation constant of sulfosalicylic acid must be known:

$$
K_{\mathrm{a}}=\frac{[\mathrm{RH}] \cdot \mathrm{h}}{\left[\mathrm{RH}_{2}\right]}
$$

Further, the following equations are valid:

$$
\begin{gathered}
{[\mathrm{R}]_{\mathrm{t}}=[\mathrm{RH}]+\left[\mathrm{RH}_{2}\right]+[\mathrm{FeR}]+2\left[\mathrm{FeR}_{2}\right]+3\left[\mathrm{FeR}_{3}\right]} \\
\mathrm{h}=[\mathrm{H}]_{\mathrm{t}}-[\mathrm{OH}]_{\mathrm{t}}+[\mathrm{FeR}]+2\left[\mathrm{FeR}_{2}\right]+3\left[\mathrm{FeR}_{3}\right]-\left[\mathrm{RH}_{2}\right]+[\mathrm{FeOH}]+ \\
+2\left[\mathrm{Fe}(\mathrm{OH})_{2}\right]+2\left[\mathrm{Fe}_{2}(\mathrm{OH})_{2}\right]
\end{gathered}
$$

where $[R]_{t}$ is the stoichiometrical concentration of sulfosalicylic acid and $[\mathrm{H}]_{\mathrm{t}}$ and $[\mathrm{OH}]_{\mathrm{t}}$ are the stoichiometrical concentrations of hydrogen ion and hydroxyl ion resp.

From equations (6) and (7) the following equation is obtained:

$$
[\mathrm{R}]_{\mathrm{t}}-\mathrm{h}=[\mathrm{RH}]+2\left[\mathrm{RH}_{2}\right]-\underset{-2}{\left.-\mathrm{H}]_{\mathrm{t}}+[\mathrm{FH}]_{2}(\mathrm{OH})_{2}\right]}-[\mathrm{FeOH}]-2\left[\mathrm{Fe}(\mathrm{OH})_{2}\right]-
$$

or

$$
\begin{gathered}
{[\mathrm{RH}] \cdot\left(1+\frac{2 \mathrm{~h}}{K_{\mathrm{a}}}\right)=[\mathrm{R}]_{\mathrm{t}}+[\mathrm{H}]_{\mathrm{t}}-[\mathrm{OH}]_{\mathrm{t}}-\mathrm{h}+[\mathrm{FeOH}]+2\left[\mathrm{Fe}(\mathrm{OH})_{2}\right]+} \\
+2\left[\mathrm{Fe}_{2}(\mathrm{OH})_{2}\right]
\end{gathered}
$$

From this equation [RH] may be calculated.

When the values of $x_{1}$ and $x_{2}$ had been estimated as mentioned above, the value of $\frac{[\mathrm{RH}]}{h}$ was increased, usually by decreasing $h$. At sufficiently low $h$ values the complex $\mathrm{FeR}_{3}$ was formed. Now $\varkappa_{3}$ could be estimated from equation (3), which could be transformed:

$$
\left[\left(\mathrm{b}-x^{\prime}\right) \frac{\mathrm{h}}{[\mathrm{RH}]}-x_{1}\right] \frac{\mathrm{h}}{[\mathrm{RH}]}=x_{2}+x_{3} \cdot \frac{[\mathrm{RH}]}{\mathrm{h}}
$$

Acta Chem. Scand. 8 (1954) No. 2 


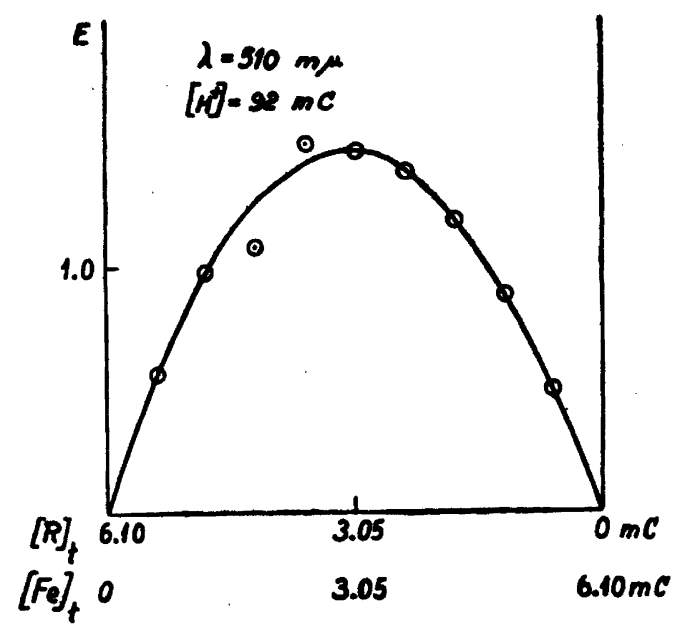

Fig. 1. Extinction (E) of various mixtures of $\mathrm{Fe}$ (III) and sulfosalicylic acid.

Here too a straight line should be formed when the left member is plotted against $\frac{[\mathrm{RH}]}{\mathrm{h}}$. The intercept will give the value of $x_{2}$ and the slope $x_{3}$.

Complexes with more than three $\mathrm{R}$ per iron atom have not been found in this investigation. This is in agreement with the supposition that chelate compounds are formed. As $\mathrm{Fe}$ (III) has the coordination number six, only three molecules $R$ can be bound to one atom of Fe.

Photometric determinations

The values of the complexity constants which have been estimated potentiometrically have also been verified photometrically.

According to $\mathrm{Job}^{9}$ the composition of a complex may be determined by the method of continuous variations. Using the same method the complexity constants may also be calculated. - In acid solution ( $\mathrm{pH}$ about 2) sulfosalicylic acid and $\mathrm{Fe}$ (III) form a violet solution with extinction maximum at $510 \mathrm{~m} \mu$. By Job's method it was shown that this complex is built up from 1 molecule of $\mathrm{R}$ and 1 atom of $\mathrm{Fe}$ (Fig. 1). The measurements have not been used to calculate the complexity constant.

The same method could not be used to determine the composition of the orange and the yellow complexes formed at higher $\mathrm{pH}$ values. This is because the different complexity constants are so close to each other. Even if most of the iron (III) is in one complex form, a certain amount will be in another form (Fig. 2). The different complexes also have their extinction maxima so near each other (Fig. 3) that the extinction at one wave length will result from at least two different complexes. Another reason why Job's method could not be used is that, when the concentration of $\mathrm{R}$ is low, $\mathrm{Fe}$ (III) will be hydrolyzed or even precipitated. 
Fig. 2. Distribution of $\mathrm{Fe}$ (III) (in percent) over $\mathrm{Fe}+3, \mathrm{FeR}, \mathrm{FeR}_{2}^{-3}$ and $\mathrm{FeR}_{3}^{-8}$, as $a$ function of $\log \mathrm{h}$ ( $\mathrm{h}$ in $\mathrm{mC})$.

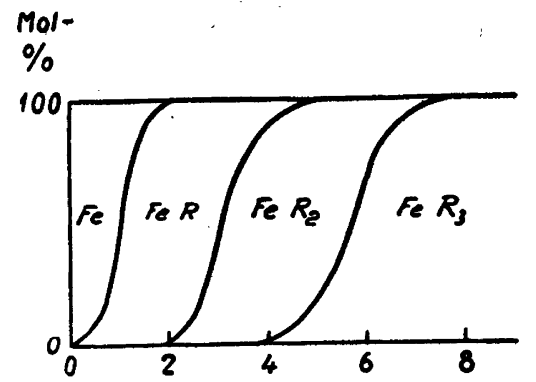

Another photometric method has been used instead to estimate the complexity constants. The principle is the same as that used by Heller and Schwarzenbach ${ }^{10}$ but is modified here so that it may be also used when two complexes absorb light at the same wave length.

If only one complex is formed the following equations are valid:

$$
\begin{gathered}
x_{n}=\frac{h^{n} \cdot\left[\mathrm{Fe} R_{n}\right]}{[\mathrm{RH}]^{\mathrm{n}} \cdot[\mathrm{Fe}]} \\
{[\mathrm{Fe}]_{\mathrm{t}}=[\mathrm{Fe}]+\left[\mathrm{FeR} \mathrm{R}_{\mathrm{n}}\right]=\mathrm{c}_{\mathbf{1}}}
\end{gathered}
$$

(No appreciable amounts of hydroxyl complexes are formed)

$$
\begin{gathered}
{[\mathrm{R}]_{\mathrm{t}}=[\mathrm{RH}]+\left[\mathrm{RH}_{2}\right]+\mathrm{n}\left[\mathrm{FeR}_{\mathrm{n}}\right]=\mathrm{c}_{2}} \\
E=\varepsilon_{\mathbf{n}} \cdot[\mathrm{FeR} \mathrm{n}] \\
\frac{[\mathrm{RH}] \cdot \mathrm{h}}{\left[\mathrm{RH}_{2}\right]}=K_{\mathbf{a}}
\end{gathered}
$$

where $E=$ the extinction of the solution in a $1 \mathrm{~cm}$ cell $\varepsilon_{\mathrm{n}}=$ the molar extinction.

Fig. 3. Extinction curves of the three complexes $\mathrm{FeR}, \mathrm{FeR}_{2}^{-3}$ and $\mathrm{FeR}_{3}^{-6}$.

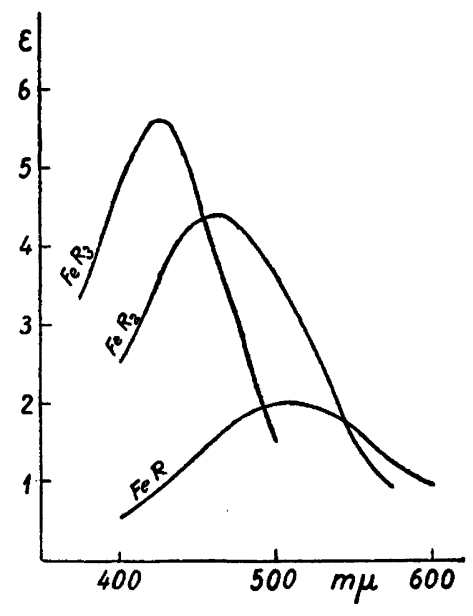

Acta Chem. Scand. 8 (1954) No. 2 
By substitution in (1) the following equation is obtained:

$$
\varkappa_{\mathrm{n}}=\frac{\mathrm{h}^{\mathrm{n}} \cdot \frac{E}{\varepsilon_{\mathrm{n}}}}{\left(\mathrm{c}_{2}-\mathrm{n} \frac{E}{\varepsilon_{\mathrm{n}}}\right)^{\mathrm{n}}\left(\frac{K_{\mathrm{a}}}{\mathrm{h}+K_{\mathrm{a}}}\right)^{\mathrm{n}}\left(\mathrm{c}_{1}-\frac{E}{\varepsilon_{\mathrm{n}}}\right)}
$$

Two cases may be distinguished:

1. If $c_{2} \gg c_{1}$ the term $n \frac{E}{\varepsilon_{n}}$ in the denominator can be neglected and one obtains:

$$
\frac{\mathrm{c}_{1}}{E}=\frac{1}{\varepsilon_{\mathrm{n}}}+\left[\frac{\mathrm{h}^{\mathrm{n}}}{\mathrm{c}_{\mathbf{2}}^{\mathrm{n}}\left(\frac{K_{\mathrm{a}}}{\mathrm{h}+K_{\mathrm{a}}}\right)^{\mathrm{n}}}\right] \cdot \frac{1}{x_{\mathrm{n}} \varepsilon_{\mathrm{n}}}
$$

If $\mathrm{c}_{1} / E$ is plotted against the expression in the square brackets a straight line is obtained. The intercept equals $\frac{1}{\varepsilon_{n}}$ and the slope is $\frac{1}{\varepsilon_{n} \varkappa_{n}}$.

2. If $\frac{1}{n} c_{2}=c_{1}=c$ equation (13) gives:

$$
\frac{\mathrm{c}}{E}=\frac{1}{\varepsilon_{\mathrm{n}}}+\left(\frac{1}{\varepsilon_{\mathrm{n}} \boldsymbol{\kappa}_{\mathrm{n}}}\right)^{\frac{1}{\mathrm{n}+1}} \cdot\left[\left(\frac{\mathrm{h}}{\mathrm{n} E \frac{K_{\mathrm{a}}}{\mathrm{h}+K_{\mathrm{a}}}}\right)^{\frac{\mathrm{n}}{1+\mathrm{n}}}\right]
$$

A straight line is obtained if $\frac{c}{E}$ is plotted against the function in the square brackets. The intercept is $\frac{1}{\varepsilon_{n}}$ and the slope $\left(\frac{1}{\varepsilon_{n} \varkappa_{n}}\right)^{\frac{1}{1+n}}$.

On the other side, if the iron forms two different complexes which both contribute to the extinction at one wave length, and no other forms of iron are present, the following equations are obtained:

$$
\begin{gathered}
\frac{x_{n}}{x_{n-1}}=\frac{h \cdot\left[\mathrm{FeR}_{n}\right]}{[\mathrm{RH}] \cdot\left[\mathrm{FeR}_{\mathrm{n}-1}\right]} \\
E=\varepsilon_{\mathrm{n}} \cdot\left[\mathrm{FeR}_{\mathrm{n}}\right]+\varepsilon_{\mathrm{n}-1} \cdot\left[\mathrm{FeR}_{\mathrm{n}-1}\right] \\
{[\mathrm{Fe}]_{\mathrm{t}}=\left[\mathrm{FeR}_{\mathrm{n}}\right]+\left[\mathrm{FeR}_{\mathrm{n}-1}\right]=\mathrm{c}}
\end{gathered}
$$

These equations may be combined to give

$$
\frac{\mathrm{c}}{E}=\frac{1}{\varepsilon_{\mathrm{n}}}+\frac{\varkappa_{\mathrm{n}-1}}{\varepsilon_{\mathrm{n}} \varkappa_{\mathrm{n}}} \cdot\left[\frac{\mathrm{h}}{[\mathrm{RH}]} \cdot \frac{E-\mathrm{c} \varepsilon_{\mathrm{n}-1}}{E}\right]
$$

where $\frac{c}{E}$ is a linear function of the expression in the square brackets. When $n=1$ this equation will be identical with (14) and (15) if $\varepsilon_{n-1}=\varepsilon_{0}=0$.

By chosing suitable pH ranges from Fig. 2 it is thus possible to estimate the complexity constants $x_{1}, x_{2}$ and $x_{3}$ photometrically.

Acta Chem. Scand. 8 (1954) No. 2 


\section{EXPERIMENTAL}

Apparatus. The measurements were made with an apparatus essentially the same as that described by Forsling, Hietanen and Sillén ${ }^{11}$. Nitrogen was passed through the reaction mixture, the gas being first freed from oxygen using a Meyer-Ronge ${ }^{12}$ oven and then from carbon dioxide using soda-lime. In order to avoid evaporation the gas was bubbled through a $3000 \mathrm{mC}$ solution of $\mathrm{NaClO}_{4}$.

The potential of the glass electrode was measured with a valve potentiometer (type Radiometer PHM 3). The redox potential was measured with a potentiometer having a sensitivity of $0.01 \mathrm{mV}$.

The photometric measurements were made with a Beckman spectrophotometer model B.

Chemicals. A solution of iron (II) perchlorate was made by Lindstrand's ${ }^{13}$ method from perchloric acid (A.R.) and iron (II) sulfide (A.R.) Iron (III) perchlorate was made by adding perchloric acid and hydrogen peroxide. The concentrations of the solutions were determined cerimetrically, if necessary after passage through a cadmium reductor. The concentration of $\mathrm{ClO}_{4}^{-}$was determined using an ion exchange technique. The hydrogen ion concentration was determined by difference, $\left([\mathrm{H}+]=\left[\mathrm{ClO}_{4}^{-}\right]-3\left[\mathrm{Fe}^{+3}\right]-2\left[\mathrm{Fe}^{+2}\right]\right)$.

Sodium perchlorate was made from perchloric acid (A.R.) and sodium carbonate(A.R.) added in deficit. After removing the carbonic acid using nitrogen gas, the solution was carefully neutralized with $\mathrm{NaOH}$ (A.R.). The concentration was determined using an ion exchange technique.

Sulfosalicylic acid was neutralized with one equivalent of sodium carbonate (A.R.) in hot solution. On cooling, the monosodium salt of sulfasalicylic acid crystallized and the salt was washed with a little water, alcohol and ether. After redissolving in water, sodium carbonate (A.R.) was added and the concentration was determined using an ion exchange technique.

Determination of the dissociation constant of sulfosalicylic acid. Before the complexity constants could be calculated, the dissociation constant, $K_{\mathrm{a}}$, of the acid had to be determined. To a known amount of the di-sodium salt of the acid, an excess of perchloric acid was added and the solution titrated with $\mathrm{NaOH}$ using a quinhydrone electrode. From nine points of the titration curve, $K_{\mathrm{a}}$ was calculated. The mean value of these calculations was taken as $K_{\mathrm{a}}$ (Table 1 ).

Table 1. Determination of the dissociation constant, $K_{\mathrm{a}}$, of sulfosalicylic acid.

\begin{tabular}{|c|c|c|c|}
\hline$[\mathrm{R}]_{\mathrm{t}}$ & {$[\mathrm{H}]_{\mathrm{t}}$} & $\mathrm{h}$ & $K_{\mathrm{a}}$ \\
\hline 19.00 & 14.90 & $\mathbf{3 . 3 5 5}$ & 2.17 \\
18.57 & 12.25 & 2.410 & 2.14 \\
18.36 & 10.97 & 2.039 & 2.15 \\
18.16 & 9.72 & 1.685 & 2.12 \\
17.97 & 8.49 & 1.365 & 2.07 \\
17.77 & 7.29 & 1.141 & 2.15 \\
17.40 & 4.97 & 0.694 & 2.13 \\
17.04 & 2.75 & 0.344 & 2.09 \\
16.87 & 1.67 & 0.206 & $\mathrm{2.17}$ \\
& & & $\mathrm{M}=2.13 \pm 0.06 \mathrm{mC}$ \\
\hline
\end{tabular}

\section{Potentiometric experiments}

The measurements were made in the following manner. A solution of $\mathrm{Fe}$ (II) and $\mathrm{Fe}$ (III) perchlorate which was acidified with a suitable amount of $\mathrm{HClO}_{4}$, was "titrated" with a solution of the disodium salt of sulfosalicylic acid. At the same time an iron solution was added, so that the total concentrations of $\mathrm{Fe}$ (II) and $\mathrm{Fe}$ (III) were kept constant during the experiment. After each addition the emf was determined and it was usually found that equilibrium was attained after 15 minutes.

Acta Chem. Scand. 8 (1954) No. 2 
Table 2. Potentiometric determination of the complexity constants $x_{1}$ and $x_{2}$.

\begin{tabular}{|c|c|c|c|c|c|c|}
\hline$[R]_{t}$ & $E$ & $E_{\mathrm{Gl}}$ & $\mathrm{b}$ & $\mathrm{h}$ & $\frac{[\mathrm{RH}]}{\mathrm{h}}$ & $\left(\mathrm{b}-x^{\prime}\right) \frac{\mathrm{h}}{[\mathrm{RH}]}$ \\
\hline 1 & 2 & $\mathbf{3}$ & 4 & 5 & 6 & 7 \\
\hline & 442.3 & & & & & \\
$*$ & & & & & \\
2.900 & 302.7 & -73.9 & 227.93 & 1.523 & 0.4429 & 512 \\
5.510 & 258.2 & -81.6 & 1292.9 & 1.128 & 1.996 & 647 \\
7.871 & 233.4 & -87.4 & 3396.0 & 0.900 & 4.351 & 781 \\
10.018 & 215.0 & -91.0 & 6951.2 & 0.783 & 6.991 & 994 \\
11.978 & 200.2 & -94.3 & 12367 & 0.688 & 10.193 & 1213 \\
13.775 & 187.2 & -97.7 & 20512 & 0.603 & 14.21 & 1443 \\
15.428 & 177.1 & -99.5 & 30391 & 0.562 & 17.61 & 1726 \\
16.954 & 168.0 & -101.8 & 43018 & 0.514 & 21.91 & 1963 \\
18.367 & 160.4 & -104.2 & 58215 & 0.468 & 26.94 & 2161 \\
19.679 & 153.3 & -106.1 & 76744 & 0.435 & 31.84 & 2410
\end{tabular}

* Too many figures are given in the tables in order not to introduce an appreciable error in the calculations.

The results of one experiment of this kind are given in some detail in Table 2. The results of the same experiment can be found in Table 3 (No. 5). In the first column of Table 2 the total concentration of sulfosalicylic acid is given. Column 2 shows the redox emf in $\mathrm{mV}$. The first value $\left(E_{0}\right)$ is the emf of the same solution with no sulfosalicylic acid added but to which a sufficient amount of perchloric acid was added in order to depress the hydrolysis of iron $\left(\left[\mathrm{H}^{+}\right]=67.5 \mathrm{mC}\right)$. The diffusion potential is eliminated. Column 3 gives the potential of the glass electrode. The other columns need no explanation.

Several other experiments were done in the same manner, but the conditions were varied in one respect or another. All of these experiments are collected in Table 3 and Fig. 4. In experiments 3-6 in this table the concentration of iron (III) was almost unaltered, but the concentration of iron (II) was varied from 1,5 to $14,3 \mathrm{mC}$. In spite of this variation the values of $x_{1}$ and $x_{2}$ show no trend, which shows that iron (II) does not form detectable amounts of a complex with sulfosalicylic acid under these conditions.

Table 3. Survey. of experiments for the calculation of $x_{1}$ and $x_{2}$ potentiometrically.

\begin{tabular}{|c|c|c|c|c|c|c|}
\hline \multirow{2}{*}{ No. } & \multirow{2}{*}{ Symbol } & \multicolumn{3}{|c|}{ Concentrations } & \multirow{2}{*}{$x_{1}$} & \multirow{2}{*}{$x_{2}$} \\
\hline & & $\mathrm{Fe}(\mathrm{II})$ & $\mathrm{Fe}$ (III) & $\mathbf{H}^{+}$ & & \\
\hline $\begin{array}{l}1 \\
2 \\
3 \\
4 \\
5 \\
6 \\
7\end{array}$ & $\begin{array}{l}+ \\
\hat{x} \\
x \\
\dot{\bullet} \\
\dot{0} \\
\Delta \\
\dot{0}\end{array}$ & $\begin{array}{r}0.7 \\
0.7 \\
1.5 \\
3.1 \\
6.5 \\
14.3 \\
0.7\end{array}$ & $\begin{array}{l}3.35 \\
7.53 \\
1.65 \\
1.84 \\
1.75 \\
1.85 \\
0.67\end{array}$ & $\begin{array}{c}0.4 \\
0.3 \\
0.3 \\
0.2 \\
0.3 \\
0.2 \\
22\end{array}$ & \begin{tabular}{|r|}
$\mathbf{4 2 0}$ \\
$\mathbf{4 9 0}$ \\
$\mathbf{4 5 0}$ \\
$\mathbf{5 5 0}$ \\
$\mathbf{5 5 0}$ \\
$\mathbf{4 1 0}$ \\
$\mathbf{5 0 7}$ \\
$\mathbf{M}=\mathbf{4 8 2} \pm \mathbf{7 0}$
\end{tabular} & $\begin{array}{l}62 \\
65 \\
55 \\
43 \\
63 \\
54 \\
\overline{56} \pm 9\end{array}$ \\
\hline
\end{tabular}

Acta Chem. Scand. 8 (1954) No. 2 


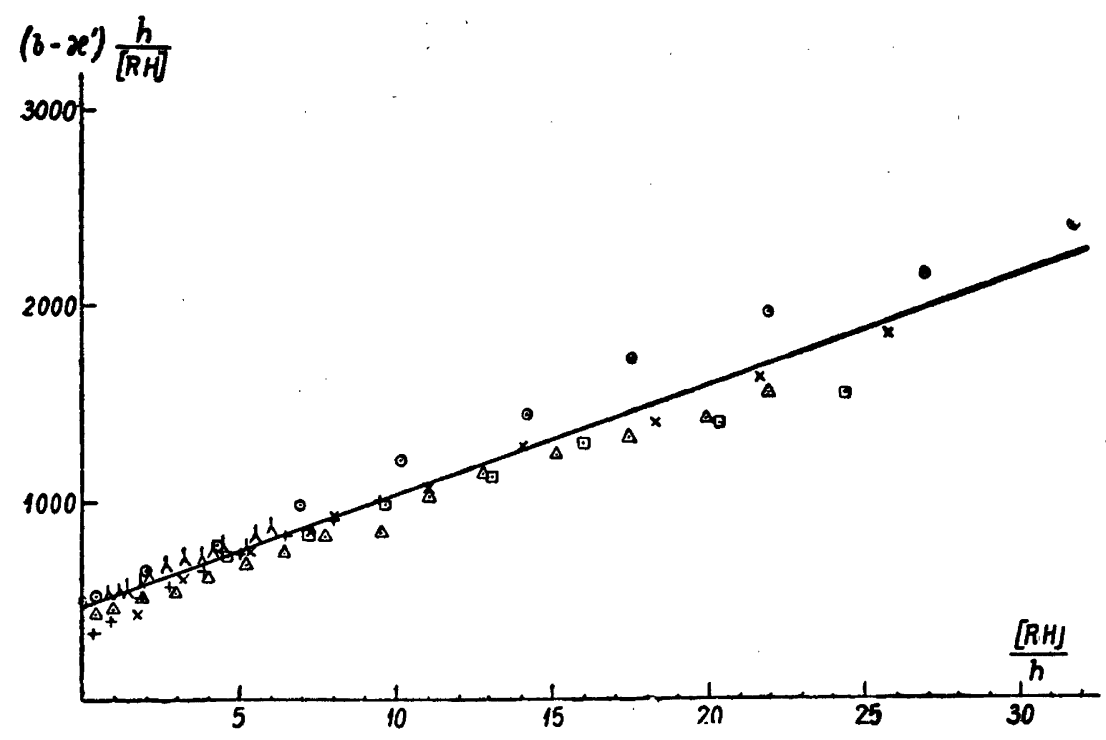

Fig. 4. Potentiometric determination of $x_{1}$ and $x_{2}$. Various total concentrations of Fe (III) and $\mathrm{Fe}$ (II). Compare Table 3.

In the experiments in Table 3 the concentration of iron (III) varied from 0.67 to $7.5 \mathrm{mC}$. No trend in the variation of $\varkappa$ can be seen and thus there seem to be no multinuclear complexes.

As may also be seen in Table 3 a variation in hydrogen ion concentration did not result in a variation in $\varkappa$. From this fact, it may be concluded that no appreciable amount of the complex FeRH is formed.

In the experiments performed to estimate the value of $x_{3}$ a technique, which differed in some respects from the preceding one, was used. Now a certain amount of sulfosalicylic acid was added to the iron solution in the beginning of the experiment. Then the hydrogen ion concentration was

Table 4. Potentiometric determination of the complexity constants $x_{2}$ and $x_{3}$.

\begin{tabular}{|c|c|c|c|c|c|c|c|}
\hline$[\mathrm{R}]_{\mathrm{t}}$ & {$[\mathrm{OH}]_{\mathrm{t}}$} & $E$ & $E_{\mathrm{Gl}}$ & b & $\mathbf{h}$ & $\frac{[\mathrm{RH}]}{\mathrm{h}}$ & $\left(\mathrm{A}-\varkappa_{1}\right) \frac{\mathrm{h}}{[\mathrm{RH}]}$ \\
\hline 1 & 2 & 3 & 4 & 5 & 6 & 7 & 8 \\
\hline $\begin{array}{l}48.62 \\
46.78 \\
45.08 \\
43.50 \\
42.75\end{array}$ & $\begin{array}{l}1.792 \\
2.671 \\
3.487 \\
4.245 \\
4.605\end{array}$ & $\begin{array}{r}532.3 \\
98.0 \\
67.0 \\
20.0 \\
-\mathbf{5 5 . 0} \\
-116.0\end{array}$ & $\begin{array}{l}-151.5 \\
-169.1 \\
-190.0 \\
-220.0 \\
-243.0\end{array}$ & $\begin{array}{l}2.193 \cdot 10^{7} \\
7.330 \cdot 10^{7} \\
4.566 \cdot 10^{8} \\
8.459 \cdot 10^{9} \\
9.087 \cdot 10^{10}\end{array}$ & $\begin{array}{l}0.0743 \\
0.0374 \\
0.0166 \\
0.00516 \\
0.00211\end{array}$ & $\begin{array}{rl} & 588.2 \\
1 & 138.2 \\
2 & 466 \\
7 & 570 \\
18 & 040\end{array}$ & $\begin{array}{r}62.6 \\
56.2 \\
74.9 \\
147.5 \\
279.2\end{array}$ \\
\hline
\end{tabular}

$$
\mathrm{A}=\left(\mathrm{b}-\boldsymbol{x}^{\prime}\right) \frac{\mathrm{h}}{[\mathrm{RH}]}
$$

Acta Chem. Scand. 8 (1954) No. 2 


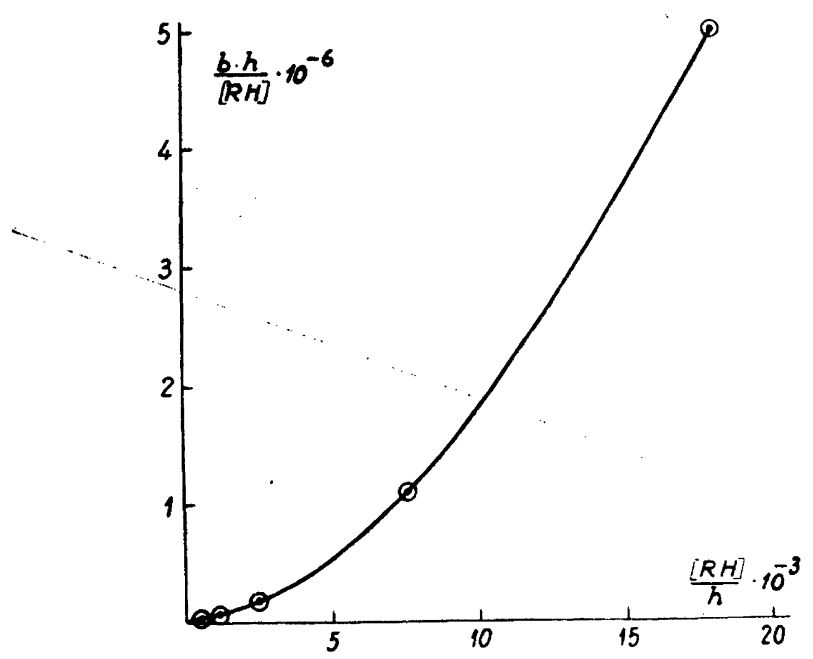

Fig. 5. Potentiometric determination of $\varkappa_{2}$ and $\varkappa_{3}$.

changed by adding $\mathrm{NaOH}$. At the same time an iron solution was added so that the total concentrations of iron (II) and iron (III) were unchanged during the experiment. Such a titration is shown in Table 4. Column 1 shows the total concentration of sulfosalicylic acid which decreases a little during the titration due to the dilution of the solution. Column 2 shows the stoichiometrically calculated concentration of hydroxyl ion if no hydrolysis or complex formation occurred. Column 8 gives the left member of equation (9). Fig. 5 shows the same experiment graphically, the expression $\frac{b \cdot h}{[\mathrm{RH}]}$ being the dependent variable. Here the curve is bent upwards, which shows that the complex $\mathrm{FeR}_{3}$ is being formed. If the expression $\left(\frac{\mathrm{b} \cdot \mathrm{h}}{[\mathrm{RH}]}-\varkappa_{1}\right) \frac{\mathrm{h}}{[\mathrm{RH}]}$ is the dependent variable the curve is a straight line, from which $\varkappa_{2}$ and $\varkappa_{3}$ may be calculated.

The results of several such experiments are collected in Table 5 .

Table 5. Survey of experiments for the calculation of $x_{2}$ and $x_{3}$ potentiometrically. Total concentration of $\mathrm{Fe}(\mathrm{III})=1.575$, of $\mathrm{Fe}(\mathrm{II})=0.158 \mathrm{mC}$.

\begin{tabular}{|c|c|}
\hline$x_{2}$ & $x_{3}$ \\
\hline 48 & - \\
42 & $0.013-$ \\
52 & 0.005 \\
46 & 0.014 \\
50 & $0.011 \pm 0.06$ \\
$M=48 \pm 6$ &
\end{tabular}

Acta Chem. Scand. 8 (1954) No. 2 
Table 6. Photometric determination of $x_{1} \cdot[\mathrm{R}]_{\mathrm{t}}=9.92 \mathrm{mC},[\mathrm{Fe}]_{\mathrm{t}}=0.3024 \mathrm{mC}$.

\begin{tabular}{|r|r|c|c|c|c|}
\hline$[\mathrm{H}]_{\mathrm{t}}$ & $\mathrm{h}$ & {$[\mathrm{RH}]$} & $E$ & $\frac{[\mathrm{Fe}]_{\mathrm{t}}}{E}$ & $\frac{\mathrm{h}}{[\mathrm{RH}]}$ \\
\hline & & & & \\
\hline 41.4 & 32.0 & 0.622 & 0.530 & 0.571 & 51.4 \\
62.0 & 52.4 & 0.388 & 0.490 & 0.617 & 135.1 \\
82.7 & 73.0 & 0.276 & 0.399 & 0.758 & 264 \\
103.1 & 92.3 & 0.236 & 0.328 & 0.922 & 391 \\
123.7 & 113.9 & 0.183 & 0.267 & 1.133 & 622 \\
\hline
\end{tabular}

Photometric experiments

Using the value of $\varkappa_{n}$ calculated above, Fig. 2 was constructed. This figure shows in which form iron (III) is present at different " $\mathrm{pH}$ " values (strictly speaking, $\log \mathrm{h}$ values). The curves are drawn on the assumption that the total concentration of sulfosalicylic acid is $10 \mathrm{mC}$ and that the concentration of iron is so low that only an insignificant amount of sulfosalicylic acid is used for complex formation. From this figure the suitable " $\mathrm{pH}$ " values may be chosen in the photometrical determinations of the complexity constants.

In the estimation of the value of $\varkappa_{1}$ the " $\mathrm{pH}$ " range chosen was $0.94-1.50$. From Fig. 2 it may be seen that in this range there is hardly any $\mathrm{FeR}_{2}$ formed. To a certain solution of iron (III) and sulfosalicylic acid there were added varying amounts of perchloric acid. Then $3000 \mathrm{mC} \mathrm{NaClO} \mathrm{Na}_{4}$ was added up to a certain volume. The hydrogen ion concentration and the extinction at $510 \mathrm{~m} \mu$ were then determined. The results are shown in Table 6 and Fig. 6 curve 1 . From this curve the following values are calculated: $\varepsilon_{1}=2.0 ; x_{1}=480$.

The experiment which was carried out in order to estimate the value of $x_{2}$ was made in the same way as the preceding one. The amounts of perchloric acid were chosen so that the " $\mathrm{pH}$ " values varied between the limits, 3.54 and 3.88. In this range, as may be seen in Fig. 2, only the complexes $\mathrm{FeR}$ and $\mathrm{FeR}_{2}$ are present in measurable amounts. The extinctions were measured at $460 \mathrm{~m} \mu$. The results are shown in Table 7 and Fig. 6 curve 2, from which the values $\varepsilon_{2}=4.4$ and $\varkappa_{2}=52$ may be calculated.

Fig. 6. Photometric determination of $\varkappa_{n}$. $\frac{[\mathrm{Fe}]_{\mathrm{t}}}{E}$ vs. $\frac{h}{[\mathrm{RH}]} \cdot \frac{E-[\mathrm{Fe}]_{\mathrm{t}} \cdot \varepsilon_{\mathrm{n}-1}}{E} \cdot \mathbf{a}$.

Curve 1: $\mathrm{n}=1 ; \mathrm{a}=3 \cdot 10^{2} ;$ scale to the left Curve 2: $\mathrm{n}=2 ; \mathrm{a}=10^{-2} ; \quad$ scale to the right Curve 3: $\mathrm{n}=3 ; \mathrm{a}=10^{-5}: \quad$ scale to the right.

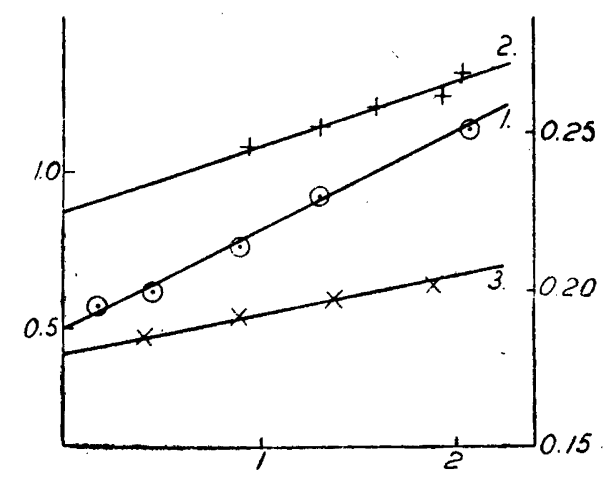

Acta Chem. Scand. 8 (1954) No. 2 
Table 7. Photometric determination of $x_{2} \cdot[\mathrm{R}]_{t}=9.92 \mathrm{mC}[\mathrm{F} e]_{t}=0.3024 \mathrm{mC}$.

\begin{tabular}{|c|c|c|c|c|c|}
\hline$[\mathrm{H}]_{\mathrm{t}}$ & $\mathrm{h}$ & {$[\mathrm{RH}]$} & $E$ & $\frac{[\mathrm{Fe}]_{\mathrm{t}}}{E}$ & $\frac{\mathrm{h}}{[\mathrm{RH}]} \cdot \frac{E-[\mathrm{Fe}]_{t} \cdot \varepsilon_{1}}{E}$ \\
\hline 0.234 & 0.133 & 8.91 & 1.228 & 0.2462 & 0.00941 \\
0.487 & 0.183 & 8.72 & 1.205 & 0.2510 & 0.01308 \\
0.741 & 0.223 & 8.63 & 1.173 & 0.2578 & 0.01584 \\
0.994 & 0.270 & 8.49 & 1.152 & 0.2625 & 0.01927 \\
1.247 & 0.291 & 8.54 & 1.125 & 0.2688 & 0.02032 \\
\hline
\end{tabular}

In the photometric determination of $x_{3}$, the " $\mathrm{pH}$ " range, 6.18-6.94, was chosen. Here most of the iron is transformed to $F e R_{3}$. No measurable amount of $\mathrm{FeR}$ is present. The experiment was made in an analogous manner to the foregoing ones. But, instead of adding perchloric acid, varying amounts of $\mathrm{NaOH}$ were added to the iron sulfosalicylic acid solution. The extinctions were measured at $425 \mathrm{~m} \mu$. The results are collected in Table 8 and Fig. 6 curve 3. From this curve the values $\varepsilon_{3}=5.6$ and $x_{3}=0.008$ may be calculated.

The values which were found photometrically agree fairly well with those found by potentiometrical measurements.

Table 8. Photometric determination of $x_{3} \cdot[\mathrm{R}]_{\mathrm{t}}=9.92 \mathrm{mC}[\mathrm{Fe}]_{\mathrm{t}}=0.151 \mathrm{mC}$.

\begin{tabular}{|c|c|c|c|c|c|}
\hline$[\mathrm{OH}]_{t}$ & $\mathbf{h}$ & [RH] & $E$ & $\frac{[\mathrm{Fe}]_{\mathrm{t}}}{E}$ & $\frac{\mathrm{h}}{[\mathrm{RH}]} \cdot \frac{E-[\mathrm{Fe}]_{\mathrm{t}} \cdot \varepsilon_{\mathrm{s}}}{E}$ \\
\hline $\begin{array}{l}0.464 \\
0.489 \\
0.515 \\
0.541\end{array}$ & $\begin{array}{l}6.56 \cdot 10^{-4} \\
4.43 \cdot 10^{-4} \\
2.68 \cdot 10^{-4} \\
1.14 \cdot 10^{-4}\end{array}$ & $\begin{array}{l}9.455 \\
9.431 \\
9.405 \\
9.379\end{array}$ & $\begin{array}{l}0.746 \\
0.768 \\
0.790 \\
0.820\end{array}$ & $\begin{array}{l}0.2027 \\
0.1969 \\
0.1914 \\
0.1844\end{array}$ & $\begin{array}{l}1.879 \cdot 10^{-5} \\
1.370 \cdot 10^{-5} \\
0.887 \cdot 10^{-5} \\
0.409 \cdot 10^{-6}\end{array}$ \\
\hline
\end{tabular}

Figure 7 shows how the complex composition of an iron solution varies with the expression $\frac{[\mathrm{RH}]}{\mathrm{h}}$. This figure is more generally valid than Fig. 2, which only shows the conditions at a certain total concentration of sulfosalicylic acid.

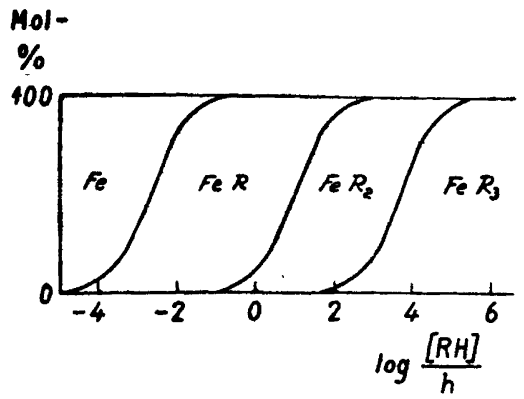

Fig. 7. Distribution of $\mathrm{Fe}$ (III) (in percent) over $\mathrm{Fe}{ }^{+3}, \mathrm{FeR}, \mathrm{FeR}{ }_{2}^{-3}$ and $\mathrm{FeR}_{2}^{-6}$, as a function of $\log \frac{[\mathrm{RH}]}{\mathrm{h}}$.

Acta Chem. Scand. 8 (1954) No. 2 


\section{SUMMARY.}

The complex formation between iron (III) and sulfosalicylic acid has been investigated. At $25.0^{\circ} \mathrm{C}$ and in a $3000 \mathrm{mC}$ solution of $\mathrm{ClO}_{4}^{-}$the following constants have been determined:

1. The dissociation constant of sulfosalicylic acid $\left(\mathrm{RH}_{3}\right.$; cf. p. 266)

$$
K_{\mathrm{a}}=\frac{\left[\mathrm{H}^{+}\right] \cdot\left[\mathrm{RH}^{-2}\right]}{\left[\mathrm{RH}_{2}^{-}\right]}=2.13 \pm 0.06 \mathrm{mC}=10^{-2.67} \pm 0.01 \mathrm{C}
$$

2. The equilibrium constants of the following reactions (both potentiometrically and photometrically):

\begin{tabular}{|c|c|c|}
\hline \multirow{2}{*}{ Reaction } & \multicolumn{2}{|c|}{ Equilibrium constants } \\
\hline & potentiometric. & photometric. \\
\hline $\begin{array}{l}\mathrm{Fe}^{+3}+\mathrm{RH}^{-2}=\mathrm{H}^{+}+\mathrm{FeR} \\
\mathrm{Fe}^{+3}+2 \mathrm{RH}^{-2}=2 \mathrm{H}^{+}+\mathrm{FeR}^{-2} \mathrm{Fe}^{-3} \\
\mathrm{Fe}^{+3}+3 \mathrm{RH}^{-2}=3 \mathrm{H}^{+}+\mathrm{FeR}_{3}^{8}\end{array}$ & $\begin{array}{ll}480 & \pm 70 \\
50 & \pm 15 \\
0.011 & \pm 0.006\end{array}$ & $\begin{array}{ll}480 & \pm 80 \\
52 & \pm 10 \\
0.008 & \pm 0.002\end{array}$ \\
\hline
\end{tabular}

3. The molar extinctions and the wave length of maxim. absorption:

\begin{tabular}{|c|c|c|}
\hline Complex & $\begin{array}{c}\text { Molar extinction } \\
\mathrm{cm}^{-1} \cdot \mathrm{mole}^{-1} \cdot 1\end{array}$ & $\begin{array}{c}\text { Wave length } \\
\lambda_{\max }\end{array}$ \\
\hline $\mathrm{FeR}$ & $2 \cdot 10^{3}$ & $510 \mathrm{~m} \mu$ \\
$\mathrm{FeR}_{2}^{-8}$ & $4.4 \cdot 10^{3}$ & $\mathbf{4 6 0} \mathrm{m} \mu$ \\
$\mathrm{FeR}_{3}^{-8}$ & $\mathbf{5 . 6} \cdot 10^{3}$ & $\mathbf{4 2 5} \mathrm{m} \mu$
\end{tabular}

Acknowledgement. My thanks are due to Professor Lars Gunnar Sillén for his great interest and the valuable discussions held with him.

\section{REFERENCES}

1. Wesp, E., and Brode, W. J. Am. Chem. Soc. 56 (1934) 1037.

2. Schwarzenbach, G. Anal. Chim. Acta 7 (1952) 141.

3. Foley, R., and Anderson, R. J. Am. Chem. Soc. 70 (1948) 1195; 72 (1950) 5609.

4. Banks, Ch., and Patterson, J. J. Am. Chem. Soc. 73 (1951) 3062.

5. Kennard, M., and Johnson C. Proc. Trans. Texas Acad. Sci. 27 (1944) 45.

6. Hedström, B. Arkiv Kemi 5 (1953) 457; 6 (1953) 1.

7. Sutton J. Nature 169 (1952) 71.

8. Biedermann, G., and Sillén, L. G. Arkiv Kemi 5 (1953) 425.

9. Job P. Ann. chim. [10] 9 (1928) 113.

10. Heller, J., and Schwarzenbach, G. Helv. Chim. Acta 34 (1951) 1876.

11. Forsling, W., Hietanen, S., and Sillén, L. G. Acta Chem. Scand. 6 (1952) 901.

12. Meyer, F., and Ronge, G. Z. angew. Chem. 52 (1939) 637.

13. Lindstrand, F. "Úber Eisenperchlorate", Thesis, Lund 1939.

Received November 3, 1953.

Acta Chem. Scand. 8 (1954) No. 2 